\title{
A Forgotten Siege the Kutul Amare Victory and the British Soldiers in Yozgat City
}

\author{
Mehmet Ertug Yavuz \\ The Foreign Languages School, Yozgat Bozok University, Yozgat, Turkey
}

Email address:

ertuyavuz37@gmail.com

\section{To cite this article:}

Mehmet Ertug Yavuz. A Forgotten Siege the Kutul Amare Victory and the British Soldiers in Yozgat City. Teacher Education and Curriculum Studies. Vol. 5, No. 3, 2020, pp. 46-52. doi: 10.11648/j.tecs.20200503.11

Received: June 28, 2019; Accepted: November 6, 2019; Published: June 20, 2020

\begin{abstract}
Kutul Amare was the second greatest victory won by the Turks during the First World War after Çanakkale This article tells you about the war from an objective perspective, how and why the war was finally politically won by the British, who was in charge at the time, how did the war progressed and how certain things changed during the time of this war, the imprisoning of the British soldiers in Yozgat City, This is what exactly makes this war so important and interesting. The (weak/ill-so called by the Europeans at those times) Ottoman forces withdrew and reinforced "Selman-i Pak", under the command of Colonel 'Bearded Nurettin Bey'. While the reinforcement continued, Mirliva-the Major General- Halil Pasha the Uncle of Enver Pasa, entered the frontline with a corps and changed the course of the battle. General Townshend, with 4500 loss regressed to Kutu'l-Amare. The Turks had a different notion of what constitutes "humane treatment" and, as they treated their own soldiers with extreme brutality, saw no reason to pamper their captives. It is recorded that: about 1,750 men had died from wounds or disease during the siege. Some 2,600 British and 9,300 Indian other ranks were rounded up and marched away. Two-thirds of the British and about a seventh of the Indians never saw their homes again. Relative to the numbers of men involved, the British losses at Kut dwarfs those of the far bigger battles on the Western Front. And some British prisoners were even got to Yozgat City to Turkey and were treated in humane manners.
\end{abstract}

Keywords: Kut'ül Amare, Victory, British, Prisoners, War, Yozgat City

\section{Introduction}

This article is going to be about the the last Turkish Victory of the Ottoman troops in Kutul's Amare which was the second greatest victory won during the First World War after Çanakkale. [1] The Kutu'l-Amare Siege can be considered as: A Forgotten victory. The famous General Townshend entering Kutu'l-Amare in $29^{\text {th }}$ September 1915 started a new forgotten page in the World history as well as the Turkish History. The victory of Kut'ül Amare, [2] which was won by the British troops under the command of Major General Charles Vere Ferrers Townshend, was the greatest victory of the First World War after Çanakkale. The Ottoman Empire lost World War I [3], and after defeat like the German and Austro-Hungarian empires, it became history. During the great war that continued from 1914 to 1918, the Ottoman Army, which had to fight on eight fronts, presented two great victories to military history with its successes in Çanakkale and then in Iraq as well as major defeats with its allies.

On April 29, 1916, the Ottoman Army defeated the Great
British Army and over 100 years have passed since the victory of Kut'ül-Amare, thousands of soldiers, five of whom were generals. This victory which took place that is now far away from where Turkey is now, could only affect the course of the Great War [4] for a short time. The wrong decisions of the big headquarters in Istanbul and Berlin 10 months later the British Army's progress could not be stopped did not prevent major collapse.

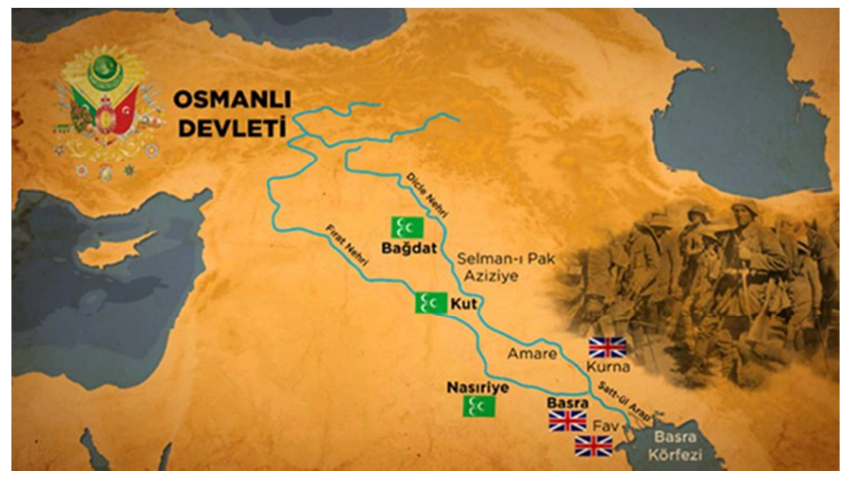

Figure 1. The Place of Kut. 


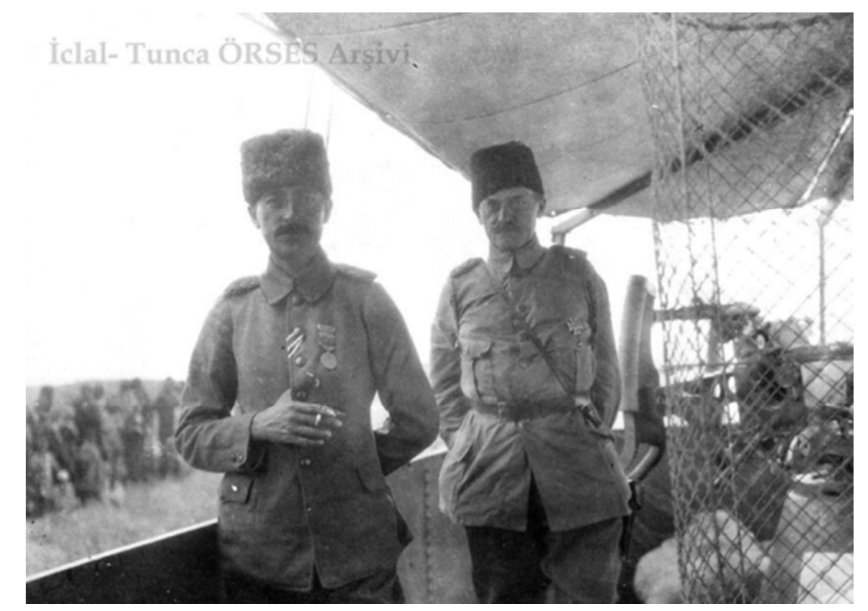

Figure 2. The Victory of the Ottoman Soldiers.

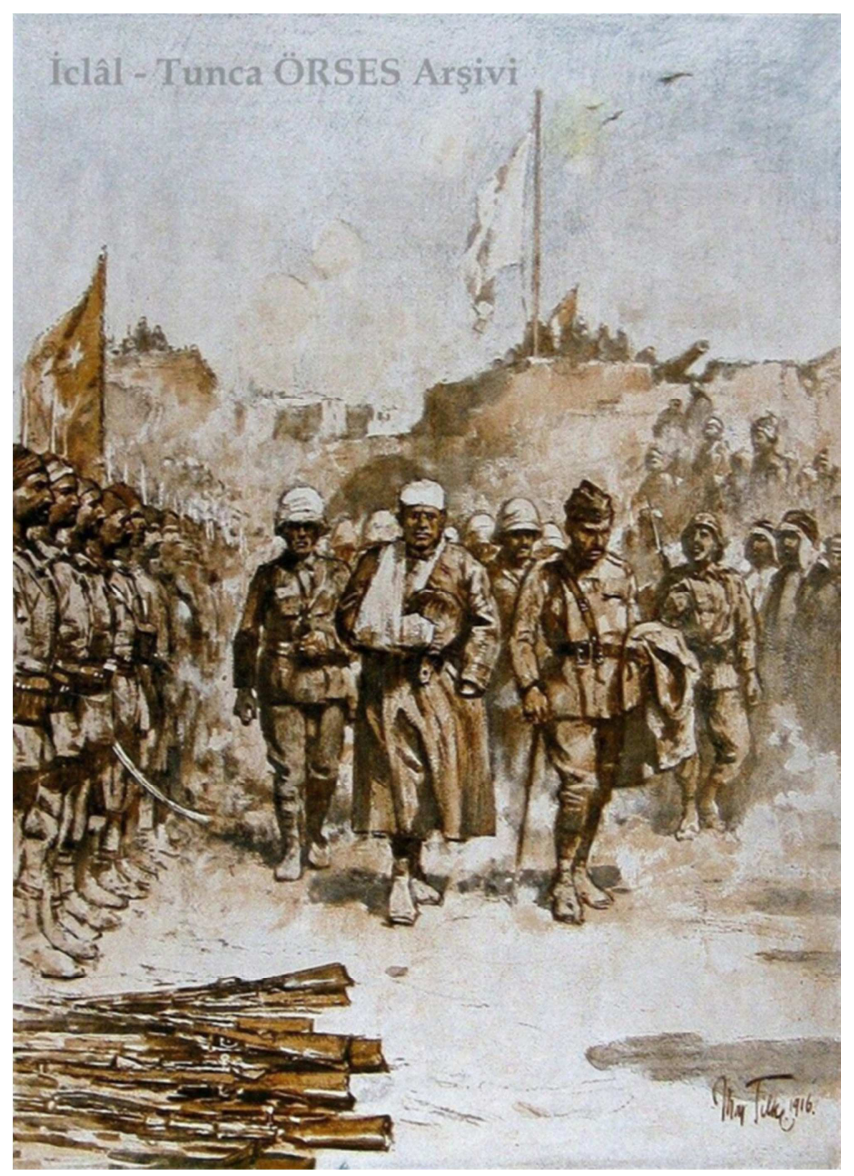

Figure 3. The Great War Kut'ül-Amare.

\section{Memories of Historians}

In this study the theme will be focused on the memories of historians, historical documents, facts and personal diaries. Some historians argue that the British felt the biggest defeat after the Yorktown defeat in America in 1781 on April 29, 1916 in Kut'ül-Amare, Iraq. Undoubtedly, the defeat of the British and their allies in Çanakkale before Kut'ül-Amare was more strategically important. The war of Kut'ül-Amare, which resulted in the surrender of hundreds of officers and thousands of soldiers, including generals, was written in history as a great defeat for England in World War I and a brilliant victory for the Ottoman Empire and its allies. However, although not as great as in Çanakkale, the victory of the great loss of people affected the course of the great war for a short time. As a result of the mistakes of the unrealistic headquarters that determined the strategy of war in Istanbul and Berlin, the recovery of the British from the Persian Gulf could not be stopped and 10 months later Kut'ül-Amare and then Baghdad did not prevent the loss. [5]

\subsection{The Ottoman and the British Armies in Kut'ül-Amare}

100 years have passed since the Ottoman Army took over the British Army in Kut'ül-Amare, 170 kilometres south of Baghdad and 350 kilometres north of the Persian Gulf. While the Turks, the British, [6] the Indians and the Germans fought and gave their lives in this land, the people of the Arabs were not even the direct side of this terrible war on their land. There were also direct supporters of the Ottomans [7] or the British, but most of the people living here had nothing to do with this. This military victory, which does not concern the people living in those regions at all and probably, they do not know, no longer has any interest or claim to that land.

In Turkey, it is celebrated as one of the few successes in the last period of the (i) Ottoman Empire.

British Poone Division (Indian Division) Commander Major General Townshend, who defeated the Ottoman army in the Battle of Selman-i Pak on November 22-23, 1915, which had about a third of his size while trying to advance to Baghdad, Major General Townshend Had he not sought refuge, perhaps this town would not have taken its place in history in any way.

(a) This battle, which started with the persistent pursuit of the Ottoman army under the command of Halil Pasha and then with the siege of Kunt Castle on December 5, 1915 and lasted until April 29, 1916, was written as a great victory in the history of Turkey with the surrender of General Townshend who realized that he would not receive the help he expected.

The Ottoman Empire entered World War I, which began in late July 1914, on October 30, the British "Mesopotamian Expedition" already started two weeks ago. The British and Indian troops set off from Bombay, India. The goal was to take control of the Persian Gulf, to break the Arabian Peninsula and Mesopotamia from the Ottoman Empire, to have Iran, which declared its neutrality, be on the side of Alliance States, to preserve its sovereignty in India, and to ensure ally Russia's relief from the south.

Three days after the Ottoman Empire officially entered the war, they landed in the Shatul-Arab region. They did not encounter great resistance, and after a few days they seized the town of Fav in the Persian Gulf and started to move north and occupied Basra on November 22nd.

Enver Pasha, the Minister of War and Deputy Commanderin-Chief, appointed Lieutenant Colonel Süleyman Military for the Ottoman forces in Iraq. One of the prominent figures of the Committee of Union and Progress, Suleyman Military's task was to stop the advance of the British with the 
troops of Muslim Arabs and hearts in the region and to take back Basra. But his powers and materials were insufficient. The plan of the Arabs to follow the call of jihad by Sultan Mehmet Reşat, who was also the Caliph, did not produce the expected result.

In the meantime, Sarıkamış Operation ended with defeat, which started on December 21, and included Enver Pasha. The Channel Operation under the command of Cemal Pasha failed (14 January 1915). On both fronts, the Ottoman armies withdrew.

The British sent new troops to Iraq, so their forces here reached the level of a corps. Gen. John Nixon was appointed commander of all units. The efforts of the Suleyman Military on the Iraqi Front also failed. He committed suicide after the failure of his attack against the British in Shuayibe, which resulted in great losses (14 April 1915).

Colonel Nurettin Bey (Sakalli Nurettin Pasha / Nurettin Ibrahim Konyar) was appointed as the commander of the Iraqi Front, meanwhile, there was a change of command in the British forces managed from the headquarters in India, Major General Charles Townshend, commander of the 6th Division within the Iraqi expeditionary force, was appointed.

(b) Nurettin Bey arrived in Baghdad on 19 May. The British troops under the command of Townshend began to advance towards the north by regressing the Ottoman forces under the command of Nurettin Bey. The retreating Nurettin Bey began preparations for defence in the south of Kut'ülAmare.

The critical situation in Iraq was viewed with concern at the headquarters in Istanbul and Berlin. Enver Pasha offered to provide the forces in the region with new reinforcements, and to reorganize under the name of VI. Army and to command the Colmar von der Goltz (Goltz Pasha), one of the German officers, who was familiar with the Turkish army. Goltz Pasha came to Istanbul 6 weeks after the war (12 December 1915) and entered the service of the Ottoman Army. After taking passive duties for a while, he was appointed as the commander of the First Army, which was responsible for protecting Istanbul and its surroundings. During his tenure, however, he was pondering the practical success of the German-Ottoman alliance, which he had been preparing for many years. Although Goltz Pasha's strategies for Mesopotamia were similar, the German and Ottoman general staff had similar differences. But at that moment, everyone was united, defending Iraq, stopping the British advance to Baghdad and expelling them from the region. Goltz Pasha first hesitated to accept the offer to take charge of this task in person. But in the end, Said "I don't know if I can endure the difficulties that this task entails in this state of my 72 years. The chances of me seeing my homeland and my family again are very low. But we have dedicated our lives to Kayzer and our homeland". Goltz Pasha, who was unable to impose the idea of the Ottoman-German armies to attack the British Army in Egypt together with the Minister of War Enver Pasha and the Ottoman Army Commander Otto Liman von Sanders, was given the command of the 6th Army in Iraq. $\mathrm{He}$ served as VI. Army Commander and Iraq Governor
General. In Istanbul, he immediately rolled up his sleeves for the establishment of the new army's headquarters. At the same time, preparations for Iran and India were continuing.

(ii) Goltz Pasha, with Turkish and German officers, diplomats, while preparing the headquarters, while the Northeast Anatolia against the Russian attacks tasked with protecting "III. The Commander of the Army Right Cenah Group, with two divisions of the troops under the command of Colonel Halil Bey, who is one year younger than his uncle Pasha, The army was ordered to join. Meanwhile, Marshal Goltz had completed the preliminary preparations in Istanbul and left after a farewell ceremony at Haydarpasa Railway Station on November 15th with a portion of the officers and personnel at his headquarters to Baghdad. In addition to Goltz, Colonel Kazim Bey (Kazim Karabekir Pasha, one of the commanders of the War of Independence), Colonel Eberhard Bopp, Turkish and German aides, Captain Ismail Hakkı Bey (son of Grand Vizier Tevfik Pasha) and Major von Restorf and representatives of the Ottoman and German foreign ministries. The other part of the headquarters, which will be completed with officers from Germany with 450 tons of material and ammunition for the needs of the headquarters, would depart later.

When he took over, Goltz, who ordered hundreds of maps of the region from Berlin as his first job, also asked the capital for ample money, German medals and insignia to distribute the local leaders in the area of responsibility to the German side. The Marshal and his entourage arrived in Baghdad on 6 December as a result of a journey first by rail and then by land and river.

\subsection{The Death of Goltz, and Halil Bey Functions}

Following the death of Goltz, Halil Bey was promoted to the rank of brigadier general on April 22. He was 33 when he became Army Commander and Governor General of Iraq. The 6th Army, which stopped the British Mesopotamian army, commanded by Sir Charles Townshend, near the ruins of Ctesiphon in northern Basra on 22 November 1915, besieged these forces in Kut'ül Amere on 8 December. The 6th Army under Halil Kut Pasha, who also repelled the British troops sent to save this army, received the Mesopotamian Army of the British Empire on April 29, 1916 after the 143-day siege. This event is regarded by British historians as the greatest military defeat of their history. Meanwhile, the British troops on the Iraq front began to move north again. On September 27, they attacked the defence line south of Kut'ül-Amare, the Ottoman forces under Nurettin Bey began to withdraw the next day. The British, who seized Kut'ül-Amare, fortified the city as the centre of their forces to move towards Baghdad. They were determined to take Baghdad as soon as possible with the effect of the defeat in Çanakkale. On the other hand, they continued to follow the withdrawal of the Ottoman troops. Nurettin Bey's Selman-i Pak region (Ctesiphon) created on the line of defence, stopped waiting for reinforcements.

Meanwhile, Nurettin Bey, who did not realize that the enemy had withdrawn, had ordered to withdraw to Baghdad 
due to the large number of losses. Realizing this situation, Halil Bey went to Nurettin Bey's headquarters with his car which was turned into a stretcher and intervened. In his memoir, he states: "At night, Mr. Nurettin decided to retreat to Baghdad, considering the heavy losses suffered by the 45th Division. But I caught up with my car. I insisted that it was them, not the ones that were us, that the enemy would be withdrawn tonight, that we would not leave the battle to him that we would immediately pursue tomorrow. Nurettin Bey accepted the situation and changed the order to withdraw with a second order. We spent that night in positions. The next morning, as I predicted, there were no enemies. " [8]

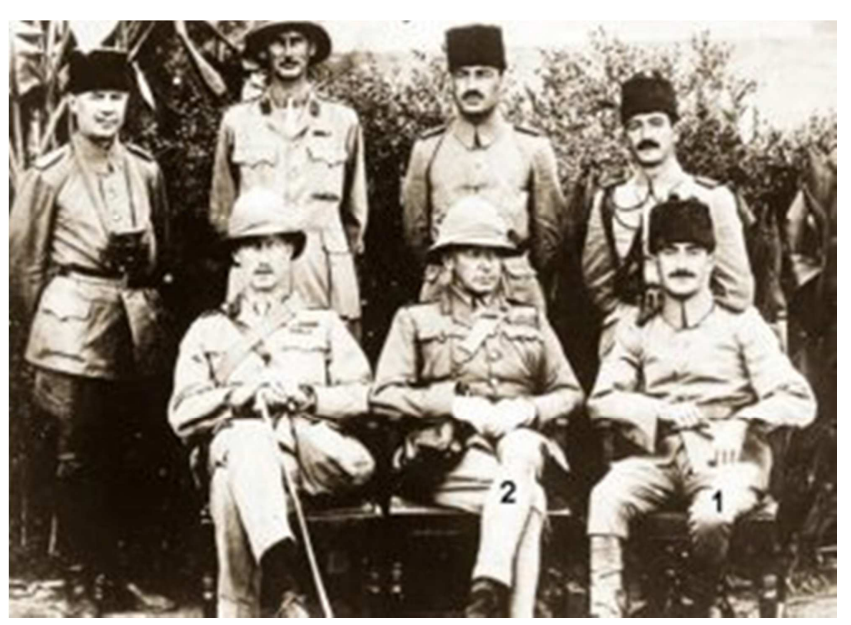

Figure 4. Ottoman and the British Soldiers.

\subsection{Million Sterling Bribery Check}

Since the beginning of April, all the British successive rescue operations have failed. Realizing that he could not get the help he was expecting, Townshend wrote a letter to Halil Pasha on April 26 and offered to meet in the middle of the Tigris River to discuss the conditions of the city. Halil Pasha accepted the offer and went to a meeting place with an engine. The interview took place at Townshend's engine. The British surrendered the city and demanded that they be allowed to withdraw to the south. In return, Townshend and his subordinates would not oppose the Ottoman Empire in World War II, but they would deliver all the weapons and ammunition they had intact. They also offered to give Halil Pasha a check of 1 million pounds. The general said that the check would be addressed to the bank that Halil Pasha wanted, and that he was given authorization from the British government to give it. Halil Pasha rejected the bribe as a ş joke ". He refused to accept any of the other offers, saying that at the end of the months of bloody warfare, they were inevitable, that they did not need any weapons and ammunition, and that they could destroy them as they wanted. He also assured them that they would not be attacked during this destruction. The British General offered to give them the guns they wanted and they wanted to guarantee safe withdrawal. One item of the proposal was to give Halil Pasha 1 million pounds. This arrogance was very angry with Halil Pasha and the meeting was interrupted. Before the Turkish soldier started the attack again, this time the famous spy Lawrence stepped in and sent news that we should make the amount of 2 million pounds. Halil Pasha ordered an offensive against this rudeness. On April 28, the British destroyed their weapons and surrendered.

\subsection{Spy Lawrence Steps in}

After returning to his headquarters, Halil Pasha received a second letter brought by a parliamentarian and an officer. This officer was the famous Spy Lawrence, who was tasked with revolting the Arab world against the Ottoman Empire. In the new letter, the amount of money offered was doubled and this time it was foreseen to be given to the Ottoman government. The other offers were the same.

Halil Pasha stated that he did not want to spend time with such negotiations at this meeting which was held on 28 April and reiterated his demand for surrender. The explosion sounds from the city that night showed that the British had destroyed all their weapons and ammunition before surrendering.

A British officer from the city later announced that they had surrendered. Halil Pasha ordered the 3rd Regiment Commander Nazmi Bey (Nazmi Pasha / Nazmi Solok, one of the commanders of the War of Independence) to prevent the Arabs in the city from attempting to plunder and disturbing the British. Nazmi Bey entered the city with the union, 14.30 'da pulled the flag to the government mansion.

Halil Pasha went to the city after publishing the victory order entitled " Orduma-To My Army “. General Townshend and all officers had gathered at the headquarters at the request of Nazmi Bey, who had taken over the city. 5 generals, 481 officers and 13,300 soldiers (some sources give these numbers slightly different) had surrendered.

Townshend welcomed Halil Pasha in his room and handed out his sword and two pistols. Halil Pasha gave the weapons he had taken back to the British general. He met with the other generals who surrendered to Townshend together and made them look cheering. He said that they would be the guest of the Sultan.

The news of victory was greeted with enthusiasm throughout the Ottoman Empire. After the Dardanelles, another great blow was hit by the British. In the same way, there was a festive atmosphere in Germany. Kaiser Wilhelm had a day off in schools. Goltz was considered a war hero and a victor. As he had imagined, he was unable to advance German influence to India through Iran, but the dangerous enemy British kept a large amount of military power outside Europe for a long time, allowing Germany to breathe on the Western front. On the evening of April 29, a ceremony was held in Baghdad. Ottoman officers and soldiers marched with torches to the tomb of Marshal Goltz. At the ceremony held in front of the tomb, the garrison commander symbolically gave the commander the title of victory. But this was the last gesture of the German presence and contribution to the war.

Halil Pasha ordered the German officers in the headquarters and troops to disappear during the take-over of Kut -ül-Amare. Goltz Pasha and the Germans were not 
mentioned in the news about the victory in the Ottoman newspapers. The Ottoman government was trying to spread the air that the victory was only the work of the Turks. After Goltz's death, VI. The relations between the Turkish and German officers in the army had deteriorated. After the victory, it got worse. Turkish officers, especially Halil Pasha, were suspicious of the activities of the Germans here and in Iran. After the Kut'ül-Amare victory, the dreams of Iran were revived both in the Ottoman and German general staff. Halil Pasha observed that the British would not give up on moving to Baghdad and that they were preparing for this purpose in the south.

But Enver Pasha insisted. They sent Halil Pasha to Iran with most of the forces in his hands. Iraq and Baghdad were weak in the face of the rapidly recovering and growing British army. On December 14, the British started moving north again. In the wars [9] exceeding 3 months, the progress of the British was slowed down, but could not be stopped. The inevitable collapse of the Ottoman army and its allies had now begun. It was a great victory of the Ottoman Army against the British in the Kut region of Iraq. So much so that the British, Turkish history books, even want to forget enough to erase the memory of the victory is a feature to be engraved. England suffered one of the greatest defeats of its history in this war of 1916, and bitterly witnessed how Turks defeated themselves in British history.

\subsection{Heavy Impact from the Turkish Army To British}

An epic heroism about the victory of Kut'ül Amare, celebrated in its centenary. An Ottoman soldier managed to drop the British warplane with his rifle. In the Siege of Kut'ül Amare, 13,000 British soldiers, 13,000 generals and 418 British officers were captured. The British forces and their allies yielded 23,000 dead and wounded.

\subsection{The Most Vile Delivery}

The British historian James Morris described the loss of Kut as "the vilest conditional surrender in British military history". This defeat aroused a huge indignation in the British press and public opinion. Thereupon, General Lake and General Gorringe were relieved of their duties in the British army and replaced by General Maude.

India's Military Contribution to the Great War [10]... Honor and Fidelity: India's Military Contribution to the Great War 1914-1918.

\subsection{Interesting Details About Kut'ül Amare Victory}

Another important importance of the Kut'ül Amare Victory [11] in terms of military [12] history was the first known airlift attempt during the siege [13] with 3 Short 184 type 225 horse planes from the Ora Base in Tigris for 26 days to replenish the nits of the British army in Kut. However, this effort was not sufficient and did not change the outcome. Halil Pasha received the surname Kut in reference to the victory of Kut'ül Amare.

IMPORTANT MESSAGE AFTER HALIL PASHA'S

\section{KUT'ÜL AMARE VICTORY!}

After the victory of Kutü'l-Amare, Halil Pasha said in his message to the 6th Army:

"Lions! Honor and glory to the Ottomans, the black square of the British land in the sunny skies of our martyrs' souls fly with joy while laughing, I congratulate your sentence by kissing all of your pure foreheads. My army has killed 350 officers and 10,000 soldiers in the face of both Kut and the armies who came to rescue Kut. But today, in Kut, 13 generals, 481 officers and 13,300 soldiers take over. The British forces, who came to the rescue of this army, returned 30,000 casualties. Looking at these two differences, there is a big enough difference to astonish the world. History will be inconvenient in finding words to write this event. Here is the first victory of Ottoman persistence broke the British stubborn in Çanakkale, the second victory here."

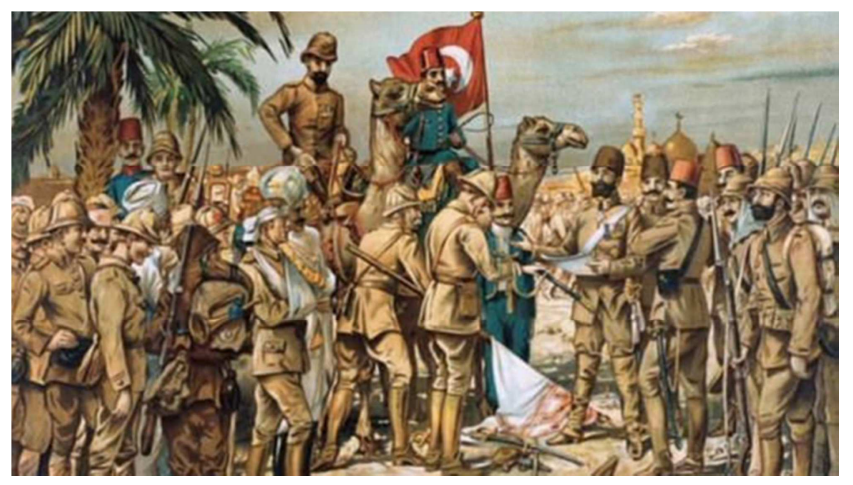

Figure 5. The second Victory after Çanakkale.

\section{TO MY ARMY}

"Lions,

Today, the glory of the Turks, over the British land, .... I kiss all of your white foreheads, I congratulate your victory.

Praise be to Allah Almighty for registering us an unread case in our history since two hundred years. Look at the grandeur of God, the first time that this case for the first time in the history of the British state was the Turkish bayonet. The war which has been going on for two years has not shown such a bright case.

My army has killed 359 officers and ten thousand soldiers in the face of both Kut and the armies coming to rescue Kut. But today I am receiving 5 generals, 481 officers and 13,300 soldiers in Kut.

The British forces, who came to the rescue of this army, returned 30,000 casualties. When you look at these two differences, you will see a big enough difference to astonish the World. History will find it hard to find words to write this case. Here we see the first case where Turkish persistence broke the British stubbornness and the second case here in Çanakkale.

This victory, which we won with our bayonet and chest alone, is the bright beginning of our success in the face of our new evolving situation. I call this day a Kut holiday. Every member of my army every day, this day to testify to our martyrs' yasinler, tebarekek, conquerors read. While our buddies still life with red blood in ulyatta and semavat, let 
our veterans be nigehban with our victories in the horse." [14]

\section{Arriving in Yozgat}

It is understood that the necessary preparations were made in Kut Amare before the British prisoners who had surrendered to the Ottoman soldiers arrived in Yozgat. The prisoners arrived at Yozgat on 30 June 1916 at 10:00.

Houses that held British prisoners after Kut'ül Amare

\section{Yozgat Houses}

The Turks had prepared two large detached houses for the prisoners. When the senior officers decided to use the lower one, captains and lieutenants gathered in the upper building. The rooms were selected and the two rooms were reserved for orders. The Turks placed guards outside the entrance doors of the house. They did not have permission to enter and exit the prisoners' house, except to go out to get water. The houses had red tiled roofs and numerous windows. The walls, which are made of stone, rubble and mud, are very thin and are approximately $23 \mathrm{~cm}$. was. The interior and exterior of the building were whitewashed. The houses were thoroughly cleaned and swept. In fact, finding the house in such a situation had been a good surprise for the prisoners. The rooms in the upstairs house were with floors and wooden ceilings. The cabinets were built into the walls. [15]

British prisoners were held in Armenian vacated houses

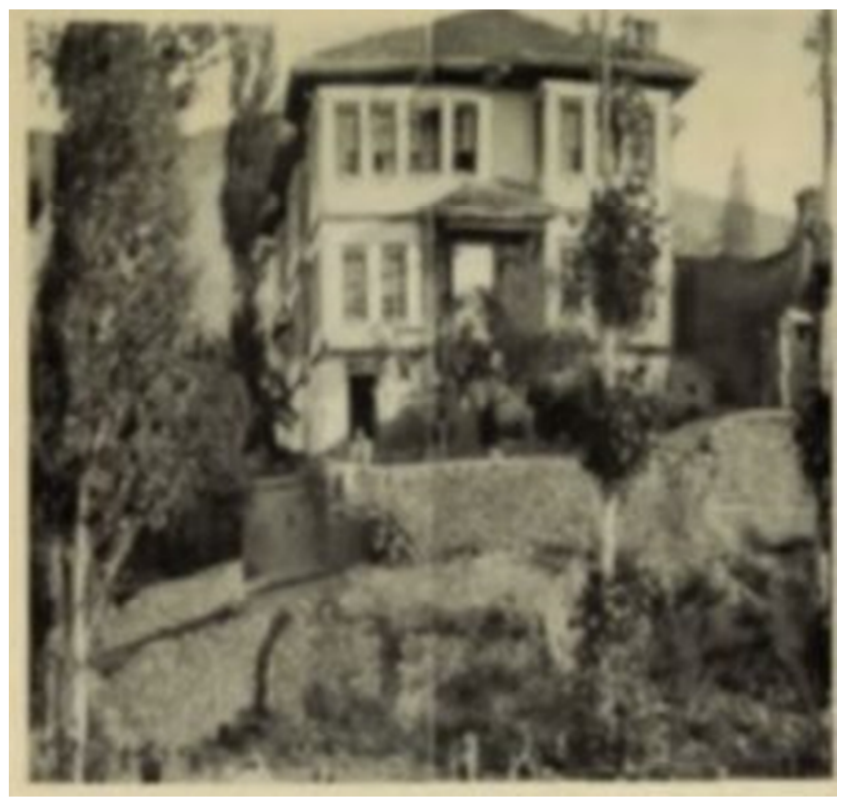

Figure 6. Yozgat City houses for the British Prisoners.

There was a large garden next to the building, which was formerly used as a hospital and accommodated by senior officers. This garden later became the exercise area of the prisoners. According to the author, these buildings, which belonged to the well-off Armenians, were confiscated at the end of 1914. On the walls of the various rooms there were small niches and pictures of Christian religion. The wooden ceilings and cabinets of these houses were carefully constructed. Some parts of the ceiling were carved with intricate ornamentation. Everything showed that the former owners were rich and well educated. At home, old exercise books were found for children with translations from Armenian to French and from French to Armenian. This shows that the former owners of the house were Armenians. Especially in many parts of Yozgat, there were empty houses and they were about to collapse. It was said that the owners of these empty houses were Armenians.

Houses Holding Kut'ül Amare Prisoners

There was no oven in the kitchen. Later, they made their own furnaces with kerosene can and mud. There were 63 people in the house where the author first settled. Considering that the ones sent to Yozgat are about 100 people, it is understood that there are 30-40 people in the other house. The main flaw in the inadequate arrangements for the comfort of the prisoners in the above house was that there was no furniture in the house. There was no furniture in the rooms of the senior officers' home, and the chairs, tables, and cedar in the dining room were laid by the contractor.

\section{Conclusion: Yozgat Memories}

The Turkish commander in charge of captives in Yozgat was Major Kazım Bey. At his disposal was a young Mülazım-1 Sani (First Lieutenant), a captain and an interpreter. He was a clerk. Kazım Bey was responsible for approximately 100 British officers. According to the author, Kazım Bey was hostile to the prisoners and ignored his wishes. He carefully avoided contact with the prisoners and did not even visit the prisoners for the first few months. The author, Major Kazim Bey, described the old school as an under-educated person who hated all Europeans. Less than a half French of the people helped to understand some of the prisoners' wishes without the help of an interpreter. His darkskinned captain did not speak any French, but spoke fluent Spanish. Moise Eskenaz, a Jewish interpreter, in his 20s, was very short. Wearing a sergeant uniform, Moise was fluent in Turkish, French and English, and spoke some German. He didn't hesitate to take bribes with chocolate or biscuits.

There were about twenty Turkish soldiers (mail) as guards at the disposal of the British [13] soldiers, and they lived in a small house next to the house of the senior officers. As time passed, Turkish guards became friendlier. Corporal Ahmet counted the prisoners in his rooms every morning. Corporal and a soldier would knock on the door before entering the room, saying good night and good night and counting. Usually both would say good night in the morning in courtesy, but later learned the right words.

\section{Acknowledgements}

All the information in this article is held in Kut'ül Amare by the British Major E. W. C. It was collected from SANDES 'diary, 1919. 


\section{References}

[1] Days of Yozgat (1916-17) of a Kutul Amare War Prisoner (Major E. W. C. Sandes) - İsmet Üzen, M. Şah Özcan-1st International Bozok Semp.5-7 May, 2016.

[2] “The Road to Endore-"E. H. John Lane Company 1920.

[3] Edward J. Erickson, Ottoman Army Effectiveness in World War I: A comparative study, Routledge, 2007, ISBN 978-0415-77099-6, p. 93.

[4] Spooner, Reverend H. Private Papers; Imperial War Museum Documents 7308. Entry for the 16th April 1916 (quoted by Rogan 2016 p. 263).

[5] New York The James A. McCann Comp., Major General Charles Mere Townshead, digitized by the New York Public Library, 1944.

[6] http://www.karar.com/yazarlar/hakan-albayrak/su-kizgintopragin-gunesli-semasinda-890.

[7] Herbert, Edwin (2003). Small Wars and Skirmishes 1902 1918: Early Twentieth-Century Colonial Campaigns in Africa, Asia and the Americas. Nottingham, Foundry Books Publications. ISBN 1-901543-05-6.

[8] Qureshi, M Naeem (1999). Pan-Islam in British Indian Politics: A Study of the Khilafat Movement, 1918-1924. Brill Academic Publishers. ISBN 90-04-11371-1.

[9] Rogan, Eugene (2016). The fall of the Ottomans. Penguin Books.

[10] Spackman, Tony, ed. (2008). Captured at Kut, Prisoner of the Turks: The Great War Diaries of Colonel W. C. Spackman. Pen \& Sword Military. ISBN 978-184415873-7.

[11] The Tragedy of Kut-The Guardian News Media 2019.

[12] Barber, Major Charles H. (1917). Besieged in Kut-and After. Blackwood.

[13] Braddon, Russell (1970) [1969]. The Siege. Viking Adult. ISBN 0-670-64386-6. Sykes, Peter (1921). "South Persia and the Great War". The Geographical Journal. Blackwell Publishing on behalf of The Royal Geographical Society. 58 (2): 101-116. Doi: 10.2307/1781457. ISSN.

[14] Davis, Paul K. (1994). Ends and Means: the British Mesopotamian Campaign and Commission. Associated University Presses. A Forgotten History: The Kutul Amare Siege, The Priren Digital Post, 2019.

[15] World Bulletin. Historical Events- 'A Forgotten Victory: Kutul Amare Siege'5 October 2015. 